\title{
Techniques for breeding and rearing marine calanoid copepods
}

\author{
C. J. CORKETT \\ Zoology Department, Bristol University; Bristol, England
}

KURZFASSUNG: Methoden für die Erbrütung und Zucht mariner calanoider Copepoden. Um ökologische und physiologische Kenntnisse über die verschiedenen Stadien im Lebenszyklus mariner calanoider Copepoden zu gewinnen, ist es notwendig, die Tiere in geringer Dichte und unter Einhaltung festgelegter Bedingungen zu züchten. Es werden Kulturverfahren beschrieben, die eine genaue Bestimmung der Entwicklungszeiten von Eiern und Larven bei verschiedenen Temperaturen ermöglichen. Die Eier werden in seewassergefüllten Glasröhrchen gehalten, die in Wasserbädern der jeweiligen Temperatur stehen und in 2stündlichen Intervallen überprüft, um die Schlüpfzeiten zu ermitteln. Auf diese Weise konnten zehn aus einem von der Arktis bis zu den Tropen reichenden Meeresgebiet stammende Copepoden-Arten über eine Skala von Temperaturen zum Schlüpfen gebracht werden. Die Larven werden in ähnlichen Röhrchen bei verschiedenen Temperaturen gehalten, mit dem Flagellaten Isocbrysis galbana gefüttert und zweimal täglich überprüft, um ihre Entwicklungszeiten zu bestimmen. Eine kontinuierlich hohe Futterkonzentration von 300000 bis 600000 Zellen/ml gewährleistet, daß die Entwicklungsrate nur durch die Temperatur beeinflußt wird. Mit dieser Methode konnte Acartia clansi vom Ei bis zum Copepodit I gezüchtet werden und Peudocalanus minutus vom Ei bis zum erwachsenen Weibchen. Bei zwei Arten gelang die Aufzucht neuer Generationen, und zwar der ersten Tochtergeneration von Temora longicornis und der zweiten Tochtergeneration von Eurytemora affinis. Um die Entwicklung von Pseudocalanus minutus vom Ei bis zum adulten Weibchen zu beschreiben, wurde BěLEHRÁDEKs Gleichung $\mathrm{D}=a(\mathrm{~T}-a)^{b}$ angewandt (D: Entwicklungszeit in Tagen, $\mathrm{T}$ : Temperatur, $a, b$ und $\alpha$ : Konstanten).

\section{INTRODUCTION}

AlLEN \& Nelson (1910) succeeded in keeping several Calanus finmarcbicus alive for a few weeks under laboratory conditions and stated that it should be possible to rear Calanus in the laboratory without difficulty. Since then it has become apparent that marine calanoid copepods are hard to rear and breed under laboratory conditions, and CRAwSHAY (1915) has discussed some of the early difficulties.

A distinction is made in this paper between rearing and breeding. The term rearing is used when adults, which may not be fertile, have been obtained in the laboratory from eggs or young, and breeding is applied to the production in the laboratory of one or more filial generations. Early success was achieved by A. G. Nicholls (unpublished results in Marshall \& OrR 1955, p 77) who reared three adult Calanus finmarchicus from eggs. It is only recently that success has been had 
with breeding calanoid copepods (JaCoBs 1961, ZLlLoux \& WILson 1966, CoRKeTT 1967, Mullin \& Brooks 1967, Corkett 1968, Heinle 1969).

An essential requisite of the detailed study of a species is to be able to obtain adequate supplies of animals and continuous laboratory cultures of calanoid copepods as has been described for Acartia tonsa by Zillioux \& Wruson (1966) and Zillioux (1969) are clearly needed for this end. It is difficult to use such cultures to obtain ecological and physiological information on stages in life cycles, since under crowded conditions density dependant factors are always prevalent and it is not possible to follow and obtain information on successive stages in the life cycle in mass culture. In order to measure accurately the development time of egg and larval stages it is necessary to rear calanoid copepods at very low densities under very carefully controlled conditions. These are the approaches that have been used by McLaren (1966), MCLaren et al. (1969) and Corkett \& MCLaren (1970) in investigations on the physiological controls of growth and development of marine copepods as part of a general study on productivity of copepods.

It is the purpose of this paper to review these laboratory techniques for rearing marine calanoid copepods and to show how, using these techniques, it is possible to estimate and predict development rates and so obtain information that could be used in estimating production rates. The techniques used for keeping adult Psendocalanus in the laboratory have been described in detail by CoRKETT \& URRY (1968) and will not be considered in this paper.

Use will be made of BĚLLHRÁdek's $(1935,1957)$ equation, in which rate of metabolic function (here, development time $\mathrm{D}$ in days) is given by

$$
\mathrm{D}=a(\mathrm{~T}-\alpha)^{b}
$$

where $a, b$ and $\alpha$ are constants and $\mathrm{T}$ is the temperature. The equation is fitted by conversion to $\log$ arithms to give $\log _{10} \mathrm{D}=\log _{10} a+b \cdot \log _{10}(\mathrm{~T}-a)$, and successive approximation to that value of $\alpha$ having smallest sums of squares of deviations of observed from calculated development times. The empirical superiority of this equation and the conceptual meaning of its parameters have been fully discussed by MCLAREN (1963).

\section{RESULTS}

\section{Sea water}

The methods described here used fresh natural sea water either collected far out to sea in a bucket at the same time the plankton tow was made, or taken from deep water by a pipe line that supplied the aquarium of the Fisheries Research Laboratory at Halifax, Nova Scotia, Canada. The water was filtered through a No. 1 Whatman filter paper and then stored at about $10^{\circ} \mathrm{C}$ in the dark ready for use.

Pseudocalanus minutus (KRøYer) has been shown to survive at salinities from $28.4 \%$ to $39.1 \%$ (MCLAREN et al. 1968). The salinity of the water used for experiments was between $30.4 \%$ and $31.6 \%$. 


\section{Food}

The marine chrysomonad Isocbrysis galbana PARKE $(4-8 \mu)$ has been used successfully to breed Eurytemora affinis (POPPE) and Temora longicornis (O. F. MüLLER). The flagellate has also been used to rear Pseudocalanus minutus from hatching to adult and Acartia clausi GIESBRECHT from hatching to copepodite I. Later larval stages and adults of Acartia need a larger flagellate than Isochrysis, and Rhodomonas sp. (9-14 $\mu$ ) has been used with Isochrysis to breed Acartia tonsa (ZILLIOUX \& Wilson 1966) and A. clausi (CoRkETT 1968). Isocbrysis galbana can tolerate a wide range of temperatures, thus providing a food source from $0^{0}$ to $13^{\circ} \mathrm{C}$. The flagellate is also non-toxic at the high concentrations that have been employed in the rearing and breeding experiments. Experiments showed that above a food level of $3 \times 10^{4}$ cells per $\mathrm{ml}$ development of $P$. minutus was not affected by the concentration of food (CORKETT \& MCLAREN 1970). The exact concentration of food was not, therefore, determined but was maintained, by the regular addition of algal media, at a level between 3 and $6 \times 10^{5}$ cells per $\mathrm{ml}$.

\section{Hatching of eggs}

Ripe female copepods were selected from plankton tows, placed in crystallizing dishes at about $10^{\circ} \mathrm{C}$ and fed Isocbrysis galbana. These dishes were looked at every 2 hours. Species that had eggs sacs were removed with their sacs and placed individually in $20 \mathrm{ml}$ vials in water baths covering a range of temperatures (generally from $0^{0}$ to $15^{\circ} \mathrm{C}$, but higher in tropical species). Females laying single eggs were left in the original dishes and the eggs laid during the 2-hour period were removed and placed in vials allowing not more than 3 to 8 eggs per vial. The time of laying was, therefore, known in all cases within 2 hours and, although the initial development began at $10^{\circ} \mathrm{C}$ before being transferred to the final temperature, the short period of this development can have had little effect on final development time. As the time for hatching approached, eggs were looked at every 2 hours night and day under a binocular microscope and the time of hatching of $50 \%$ of the group or sac of eggs recorded. This median value of development for a group or sac of eggs at a given temperature constitutes one experiment; wherever possible a number of such experiments were repeated in each water bath.

The temperature in the water baths generally varied by about $\pm 1^{\circ} \mathrm{C}$, but in all cases the temperature of the bath was taken very regularly, generally every 2 hours day and night. The response of development to temperature is very nearly linear over a narrow temperature range so that the mean value gives an accurate measure of the effective temperature during development and each experiment is assigned its own mean temperature. Using these techniques it has been possible to obtain accurate data on egg development as shown by the narrow range of development times. Fourteen experiments conducted on the eggs of Pseudocalanus minutus at a mean temperature for all experiments of $12.01^{\circ} \mathrm{C}$ (range $11.95^{\circ}-12.08^{\circ} \mathrm{C}$ ) gave a mean of 2.9 days (range $2.75-3.00$ days). 
In general, there are no real difficulties in obtaining successful hatching of eggs since the egg contains its own food supply and the period is short enough to be completed without changing the culture media. Tropical species may, however, present a difficulty as the higher temperature encourages bacterial growth. To obtain successful hatching of the eggs of Centropages furcatus (DANA) from Jamaica several precautions were taken. The sea water was raised to $70^{\circ} \mathrm{C}$ for 10 minutes, the vials were autoclaved and $5 \mathrm{I}$. U. per $\mathrm{ml}$ of each of the antibiotics Penicillin and Streptomycin were used in the water.

Using these methods, the eggs of Metridia longa, Calanus glacialis, C. byperboreus, Pseudocalanus minutus, Temora longicornis, Eurytemora affinis, Tortanus discaudatus, Acartia clausi, A. tonsa and Centropages furcatus have been successfully hatched over a range of temperatures (McLAREN 1966, MCLAREN et al. 1969).

\section{Rearing of naupliar stages}

Ripe females were placed in crystallizing dishes at about $10^{\circ} \mathrm{C}$ and fed Isochrysis galbana. The females were removed after a suitable number of eggs had been laid and the eggs observed twice a day. Young nauplii were removed and placed in $20 \mathrm{ml}$ vials ( 2 per vial) in water baths covering a range of temperatures from $0^{0}$ to $13^{\circ} \mathrm{C}$. The vials were one-third filled with fresh filtered sea water and one-third Erdschreiber medium containing Isocbrysis galbana. The time taken to develop from hatching of eggs to copepodite $I$ is easily determined, as the later stage can be distinguished from the preceding nauplius stage without being removed from the experimental vial. Temperatures were observed twice a day to estimate the mean temperrature during development.

\section{Rearing of copepodite stages}

The copepodites I were then placed in new vials with fresh media and the copepodites reared to adults in the same way as described for the nauplii. Observations were made once a day on 3 female Pseudocalanus minutus to try and follow

\section{Table 1}

Development times for the larval stages of Pseudocalanus minutus from hatching to adult female at $11.9^{\circ} \mathrm{C}$. N: nauplius, $\mathrm{C}$ : copepodite

\begin{tabular}{|ccc|}
\hline Development period & $\begin{array}{c}\text { Mean time } \\
\text { (days) }\end{array}$ & Range \\
\hline NI-CI & 12.3 & $11.5-12.6$ \\
CI-CII & 4.7 & $3.3-5.4$ \\
CII-CIII & 4.0 & $2.8-4.7$ \\
CIII-CIV & 4.7 & $3.2-5.7$ \\
CIV-CV & 3.8 & $2.6-5.8$ \\
CV-Adult & 6.0 & $2.6-8.0$ \\
NI-Adult & 35.5 & \\
\hline
\end{tabular}


the development under a binocular microscope. This was not very satisfactory since it was difficult to recognize different stages, but an estimate was made of the amount of time spent in each copepodite stage (Table 1).

Using these rearing techniques Pseudocalanus minutus, Temora longicornis and Eurytemora affinis were reared to adult at about $12^{\circ} \mathrm{C}$.

\section{B reeding}

The adults were then removed from the vials and a male and female placed in a crystallizing dish at about $10^{\circ} \mathrm{C}$. They were fed Isochrysis galbana and the culture media was changed weekly. The process of fertilization was not observed but first filial nauplii were produced by Temora longicornis and Eurytemora affinis. It was not possible to see if Pseudocalanus minutus were fertile as only females had been successfully reared. First filial nauplii of Eurytemora were reared to adults in crystallizing dishes at $10^{\circ} \mathrm{C}$ from which second filial nauplii were obtained.

\section{Development of Pseudocalanus minutus}

The development rate of eggs over a range of temperature has been determined (MCLAREN et al. 1969) and may be described by the equation

$$
\mathrm{D}=2144(\mathrm{~T}+13.4)^{-2.05}
$$

where $\mathrm{D}$ is the development time in days of the egg from laying to hatching and $\mathrm{T}$ is the temperature in ${ }^{\circ} \mathrm{C}$. It has been further shown by CoRKETT \& MCLAREN (1970) that when food is abundant the parameters of $\alpha=-13.4$ and $b=-2.05$ may also be used to describe the development of nauplii which may be described by the equation

$$
\mathrm{D}=9224(\mathrm{~T}+13.4)^{-2.05}
$$

where $\mathrm{D}$ is the development time in days from hatching to copepodite $\mathrm{I}$.

In effect, development time from hatching to copepodite I was shown to be the same multiple of development time for eggs to hatching at any given temperature. The same multiple may be derived by dividing the value of $a$ in BĚLEHRÁDEK's equation for the development from hatching to copepodite I by the value of $a$ for development of eggs.

Assuming that development times from copepodite I to older stages are also the same multiples of development time of eggs at any given temperature, then experiments with older stages at a sing le temperature should be sufficient to determine the value of $a$ in B̌̌LEHRÁDEK's equation for these stages and so describe development over a range of temperature.

Development from laying to hatching at $11.9^{\circ} \mathrm{C}$ took 2.85 days (equation 1), whereas development from hatching to adult female took 35.5 days (Table 1) giving a multiple of 12.46. Since $a=2144$ for development from hatching to copepodite I (equation 1) a for development from copepodite I to adult female may be assumed 
to be 26714 so that development from copepodite I to adult female is given by the equation

$$
\mathrm{D}=26714(\mathrm{~T}+13.4)^{-2.05}
$$

where $\mathrm{D}$ is the development time in days from copepodite $\mathrm{I}$ to adult female.

\section{DISCUSSION}

HeINle (1969) and ZILLIoux (1969) have successfully used artificial sea water in breeding Acartia tonsa and Eurytemora affinis. Work in progress has shown that Pseudocalanus elongatus Boeck may be successfully reared in Triton Marine salts. The use of artificial sea water is a major step towards the establishment of a fully defined media, which is essential if fully repeatable results are to be obtained.

Successful breeding of Temora longicornis and Eurytemora affinis is reported here to show that fertile adults can be reared in vials. These techniques were, however, developed for rearing copepods under controlled conditions with abundant food and would be too laborious for establishing breeding stocks. With abundant food it is argued that development will be physiological and will vary only with the physical parameters of the environment such as temperature, salinity and pressure, temperature being by far the most important. It is suggested that development of copepodite stages with food in excess is the same multiple of development of eggs (itself a physiological response since food is abundant in the egg) at any given temperature, as has been shown for development of naupliar stages in 3 species of calanoid copepods (CORKETT \& MCLAREN 1970).

\section{SUMMARY}

1. Methods are described that make it possible to raise copepod larvae at low population densities with abundant food so that development proceeds at maximum temperature-determined rates.

2. Using these techniques, eggs from ten species of calanoid copepods from the Arctic to the tropics have been hatched, two species have been reared and a further two have been bred.

3. The development of eggs and larvae with food in excess is physiological and will vary with the physical parameters of the environment. Under these conditions it is argued that development of larval stages is the same multiple of development of eggs at any given temperature.

4. BËLEHRÁDEK's equation adapted to relate development time with temperature has been used to describe and predict the development times of Pseudocalanus minutus from egg to adult female. 


\section{LITERATURE CITED}

Allen, E. J. \& Nelson, E. W., 1910. On the artificial culture of marine plankton organisms. J. mar. biol. Ass. U.K. 8, 421-474.

BĚLEHRÁDEK, J., 1935. Temperature and living matter. Borntraeger, Berlin, 277 pp. (Protoplasma-Monogr. 8.)

- 1957. Physiological aspects of heat and cold. A. Rev. Physiol. 19, 59-82.

ConketT, C. J., 1967. Technique for rearing marine calanoid copepods in laboratory conditions. Nature, Lond. 211, 481-483.

- 1968. La reproduction en laboratoire des copépodes marins Acartia clausi (GIEsBrechT) et Idya furcata (Barrd). Pelagos. Bull. Inst. océanogr. Alger 10, 77-90.

- \& McLaren, I. A., 1970. Relationships between development rate of eggs and older stages of copepods. J. mar. biol. Ass. U.K. 50, 161-168.

- \& URRY, D. L., 1968. Observations on the keeping of adult female Psendocalanus elongatus under laboratory conditions. J. mar. biol. Ass. U.K. 48, 97-105.

CRAwSHAY, L. R., 1915. Notes on experiments in the keeping of plankton animals under artificial conditions. J. mar. biol. Ass. U.K. 10, 555-576.

HeINLE, D. R., 1969. Culture of calanoid copepods in synthetic sea water. J. Fish. Res. Bd Can. 26, 150-153.

JacoBs, J., 1961. Laboratory cultivation of the marine copepod Psendodiaptomus coronatus WILLIAMS. Limnol. Oceanogr. 12, 657-666.

MCLaren, I. A., 1963. Effects of temperature on growth of zooplankton, and the adaptive value of vertical migration. J. Fish. Res. Bd Can. 20, 685-727.

- 1966. Predicting development rate of copepod eggs. Biol. Bull. mar. biol. Lab., Woods Hole 131, 457-469.

- Corkett, C. J. \& Zillioux, E. J., 1969. Temperature adaptation of copepod eggs from the arctic to the tropics. Biol. Bull. mar. biol. Lab., Woods Hole 137 (in press).

- Walker, D. A. \& CorketT, C. J., 1968. Effects of salinity on mortality and development rate of eggs of the copepod Psendocalanus minutus. Can. J. Zool. 46, 1267-1269.

Marshatl, S. M. \& OrR, A. P., 1955. The biology of a marine copepod Calanus finmarchicus (GunNERus). Oliver \& Boyd, Edinburgh, 188 pp.

MuldiN, M.M. \& Brooks, E. R., 1967. Laboratory culture, growth rate, and feeding behaviour of a planktonic marine copepod. Limnol. Oceanogr. 12, 657-666.

Zil..Joux, E. J., 1969. A continuous recirculating culture system for planktonic copepods. Mar. Biol. 4, 215-218.

- \& WILson, D. F., 1966. Culture of a planktonic calanoid copepod through multiple generations. Science, N.Y. 151, 996-998.

Author's address: C. J. CORKETT'

Department of Zoology

Bristol University

Bristol, England 